\title{
Non-Linear Performance of Strong Column Weak Beam RC Frame Building
}

\begin{abstract}
Buildings are designed in different methods for resisting the lateral loads, in which strong column weak beam concept is one of the methods of designing, this method is used to avoiding the global failure of the structure In this work 3bay 5 story RC frame building is consider for the analysis, the structures are design strong column weak beam with the help of static non-linear pushover analysis of RC frame building with increasing the percentage of column sizes $20 \%, 40 \%, 60 \%, 80 \%$ and $100 \%$. By varying with percentage of columns resistances of structure is increased. The parameters base shear, story displacement, and hinge formations in the structure is obtained from this analysis. The base shear and displacement are increased by increasing the column sizes, these parameters are discussed the results in detail. Comparing the all six model results the base shear in increased by $266.64 \%$ when the column size is increased by $100 \%$. From this analysis we can reduce the failure in the structure during the earthquake. Formation of plastic hinges in column changes to beam by increasing the column size, so increase the capacity of structure. The building is analyzed by using SAP2000.
\end{abstract}

Keywords : Base shear, plastic hinges, pushover analysis, strong column, weak beam.

\section{INTRODUCTION}

Now a day's the buildings are not only design horizontal and vertical loads, and also consider the lateral loads, wind loads. In that different methods are introduced to design the buildings in which strong column weak beam concept is one of the methods of designing. The design philosophy of strong column weak beam is realized by columns are designed by capacity design concept. The damages occur in the RC frame building due to past earthquake shown that failure may be due to utilization of poor quality of construction materials, soft story, beam-column joint connection is weakest point in the building it is fail easily when structure is subjected to lateral loads [8]. In structures the beam failure causes the only story failure but column failure causes the total failure of the structure. If in case the beam is fail it is indicated before collapse of the element by formation of cracks or deformations it can observe by seeing. But in columns it is not indicated and also not seen by observing. Most of earthquake failure of structures is failed by due to column failure. In figure.1 (a) and (b) shows the failure mechanism of strong column weak beam design building and weak column strong beam designed building. In this present study consider the 5-story 3-bay RC frame building is taken. For improving

\footnotetext{
Revised Manuscript Received on December 30, 2019.

* Correspondence Author

J.Sony*, PG student, Department of civil engineering, Anurag Group of Institutions, Hyderabad, India. Email:sonyjakkula22@gmail.com

Dr.A.vimala, HOD, Department of civil engineering, Anurag Group of Institutions, Hyderabad, India. Email: vimlareddy@gmail.com
}

(C) The Authors. Published by Blue Eyes Intelligence Engineering and Sciences Publication (BEIESP). This is an open access article under the CC BY-NC-ND license (http://creativecommons.org/licenses/by-nc-nd/4.0/) the lateral load resistance of the structure is by increasing the varying percentages of columns sizes.

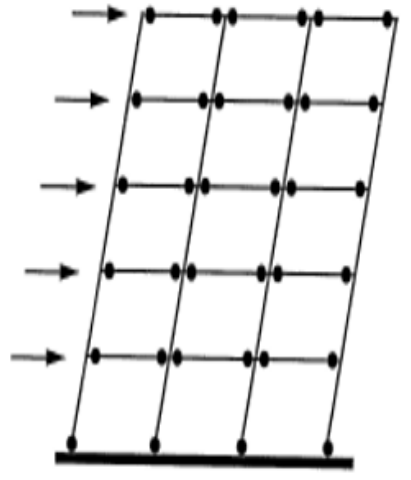

(a)

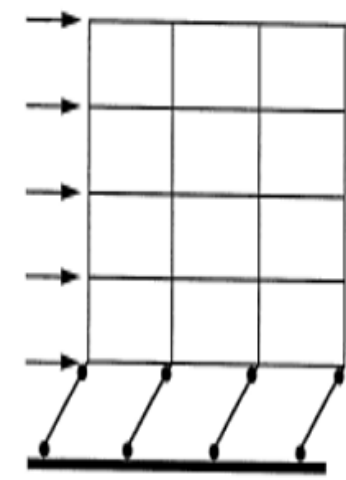

(b)
Figure1: (a) Mechanisms of Strong Column Weak Beam and (b) Weak Column Strong Beam [7]

\section{A. OBJECTIVES}

1) To study the non-linear behaviour of the strong column weak beam structures by using pushover analysis.

2) To study the variation incapacities curves of structures have been used as a way to quantify and compare their performances of the building parameters like base shear, story displacement, story drift.

\section{MODELLING AND ANALYSIS}

\section{A. BUILDING DETAILS}

This study is about 3-bay 5-story RC frame building shown in figure.2 (a) and figure.2 (b). The building details are selected based designed by IS code 456-2000, the building dimensions are selected based on literature reviews.

The geometric details and material details are shown in table.1. The elevation of building frame shown in figure.2 (b) is designed as per Indian standard code IS 456-2000 concrete frame design.

Table. I Geometric details of building

\begin{tabular}{|c|c|}
\hline No of bays in $\mathrm{X}$ and $\mathrm{Y}$ direction & 3 and 3 \\
\hline $\begin{array}{l}\text { Each bay width in } \mathrm{X} \text { and } \mathrm{Y} \\
\text { direction }(\mathrm{m})\end{array}$ & 6 and 6 \\
\hline Story height $(\mathrm{m})$ & 3 \\
\hline Grade of steel & Fe415 \\
\hline Grade of concrete & M25 \\
\hline Thickness of slab(mm) & 175 \\
\hline Cross section of beam $\left(\mathrm{mm}^{2}\right)$ & $300 \times 450$ \\
\hline Cross section of column $\left(\mathrm{mm}^{2}\right)$ & $500 \times 500$ \\
\hline Thickness of wall(mm) & 230 \\
\hline
\end{tabular}




\section{Non-Linear Performance of Strong Column Weak Beam RC Frame Building}

Loads are selected based on the IS456-2000, live Load and roof live load is considered based on the IS 875-1987 code (PART-2), earthquake load is taken as per IS 1893-2002, table. 2 shows the details of loads considered on building.

Table. II Loads considered for building

\begin{tabular}{|l|l|}
\hline Floor finish & $1.5 \mathrm{KN} / \mathrm{m}^{2}$ \\
\hline Live load & $3 \mathrm{KN} / \mathrm{m}^{2}$ \\
\hline Roof live load & $1.5 \mathrm{KN} / \mathrm{m}^{2}$ \\
\hline Earthquake load & As per IS 1893 -2002(clause 7.3 ) \\
\hline Wall load & $11.73 \mathrm{KN} / \mathrm{m}$ \\
\hline
\end{tabular}

In this work six building models are created to understand the performance level of the building under lateral loads. The building models are created with increasing column sizes $20 \%, 40 \%, 60 \%$, $80 \%$, and $100 \%$. The increase percentages of column dimensions are shown in table. 3 for all models.

Table.III By increasing the percentage of size of column

\begin{tabular}{|l|l|}
\hline \multicolumn{1}{|c|}{ Model No } & Column size(mm) \\
\hline Model-1(initial model) & $500 \times 500$ \\
\hline Model-2(20\% increasing) & $600 \times 600$ \\
\hline Model-3(40\% increasing) & $700 \times 700$ \\
\hline Model-4(60\% increasing) & $800 \times 800$ \\
\hline Model-5(80\% increasing) & $900 \times 900$ \\
\hline Model-6(100\% increasing) & $1000 \times 1000$ \\
\hline
\end{tabular}

The main disadvantages of this method are to required more quantity of materials and large area for cross section. This is only used for showing the behavior of the structure when structure is subjected to lateral loads.

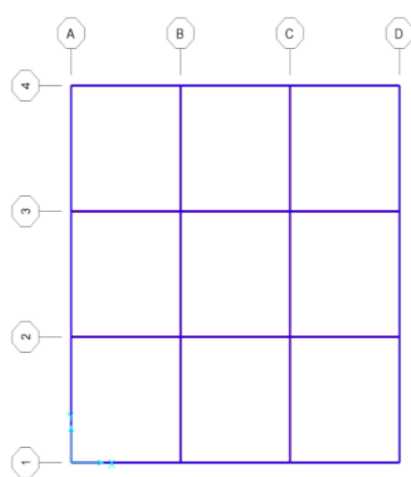

(a)

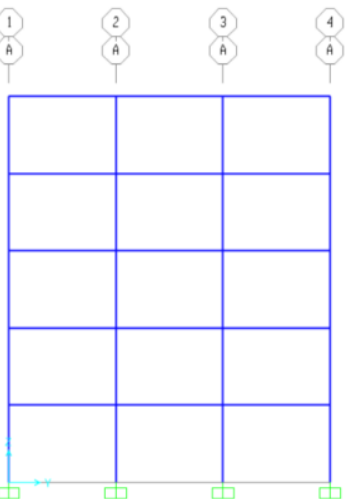

(b) of 3 bay, 5story building

Figure2 (a) \&2(b) shows Plan and Elevation of the building. Static non-linear pushover analysis is done to evaluate the performance of the all the six model of frame structures by SAP2000, results are obtained after this designed and analysis of the frame structures. The behavior of the structure like displacement, formation of plastic hinges in beams and columns are shown in graphs.

\section{B. ANALYSIS}

The static non-linear pushover analysis done to know the behavior of the structure. The structure is designed as per
Figure; 2 (a ) Plan and (b) Elevation

IS456-2000 and verify analysis and design sections match for all concrete frames, then add the pushover loads in $\mathrm{X}$-direction and $\mathrm{Y}$-direction and assign loads, then assign the hinges in beam and column sections. A computer model of a structure is subjected to lateral load patterns, the intensity of the load is increased, i.e. the structure is pushed horizontally, and the sequence of cracks, yielding, plastic hinge formations, and the load at which failure of the various structural components occurs are recorded. This incremental process continues until a predetermined displacement limit is reached. Thus, a force-displacement relationship or capacity curve is obtained, which gives a clear indication of the nonlinear response of the structure.

\section{RESULTS AND DISCUSSIONS}

\section{A. DISPLACEMENT VS BASE SHEAR}

Form the analysis of the building a comparative study has been done for the six-models it was observed in figure.3, it shows the graph drawn between displacement verses base shear it is called capacity curves or pushover curves.

Table IV: Displacement and base shear values

\begin{tabular}{|c|c|c|}
\hline Model & Displacement $(\mathrm{m})$ & $\begin{array}{c}\text { Base shear } \\
(\mathrm{kN})\end{array}$ \\
\hline 1 & 0.2465 & 5141.198 \\
\hline 2 & 0.2365 & 6060.095 \\
\hline 3 & 0.3945 & 9203.338 \\
\hline 4 & 0.4669 & 12650.07 \\
\hline 5 & 0.5075 & 15220.67 \\
\hline 6 & 0.5456 & 18850.05 \\
\hline
\end{tabular}

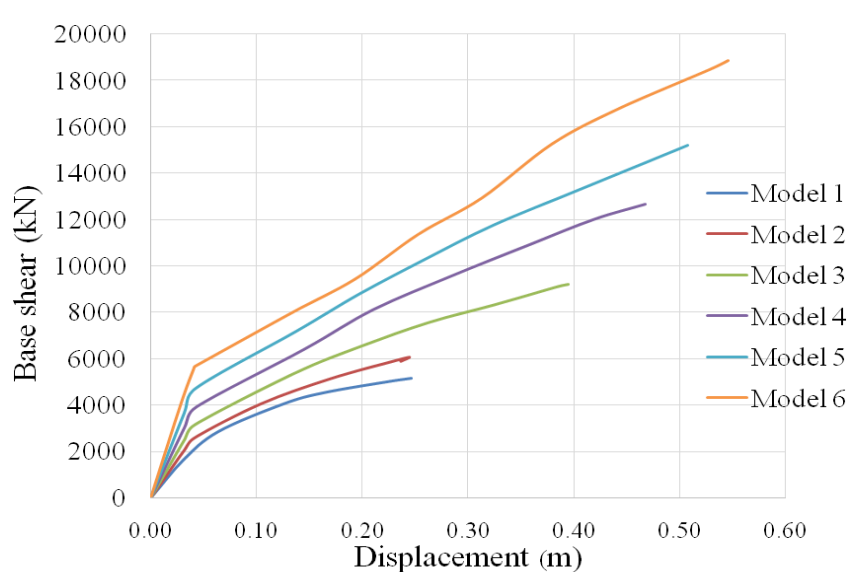

Figure: 3 Displacement versus base shear curve

in order to increasing the size of column base shear also increases.

Published By: 
In model-2 Base shear is increased by $17.87 \%$ when the column size is increased by $20 \%$ compared to model-1. In model-3 Base shear is increased by $79.01 \%$ when the column size is increased by $40 \%$ compared to model- 1 . In model-4 Base shear is increased by $146.05 \%$ when the column size is increased by $60 \%$ compared to model-1. In model-5 Base shear is increased by $196.05 \%$ when the column size is increased by $80 \%$ compared to model- 1 . In model- 6 Base shear is increased by $266.66 \%$ when the column size is increased by $100 \%$ compared to model-1

\section{B. PLASTIC HINGE FORMATIONS}

The formation of plastic hinges in the frame models vary from one model to another model, these typical plastic hinge formations for all considered frame models are shown in figure-4. Based on performance level we decide non-linear behavior of the structure.

In figure 4(a) shows the distribution of hinge formations in model-1, frame is considered in XZ plane @ Y=0 hinges are formed in all stories of building in the range of B-LS, the story columns are within the life safety. Frame model shows that first yield occurred at a displacement of $0.1252 \mathrm{~m}$ with base shear of $4035.93 \mathrm{kN}$ and ultimate base shear was

$5141.19 \mathrm{kN}$ with a displacement of $0.2465 \mathrm{~m}$.

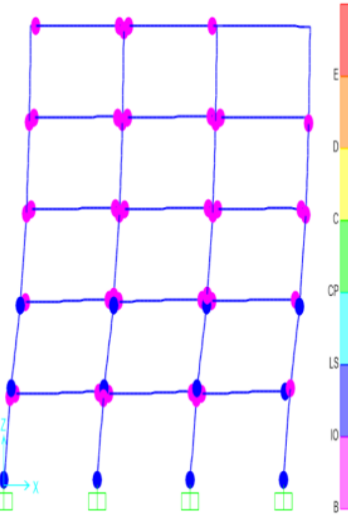

(a)

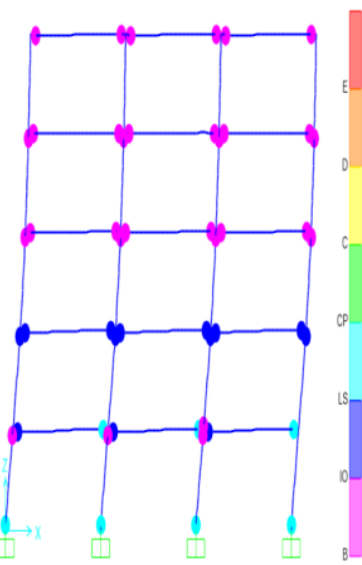

(c)

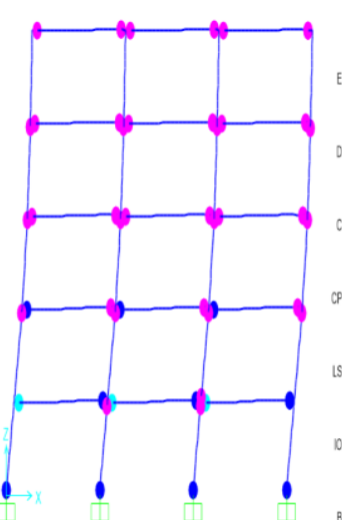

(b)

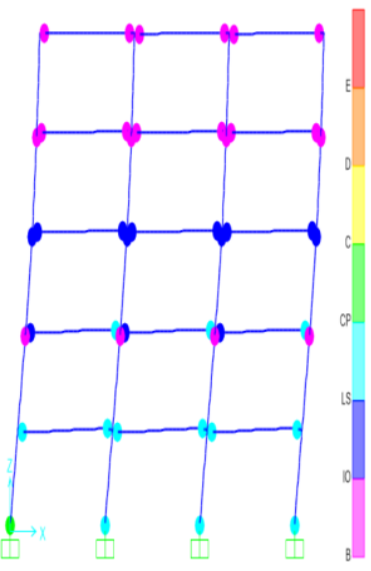

(d)

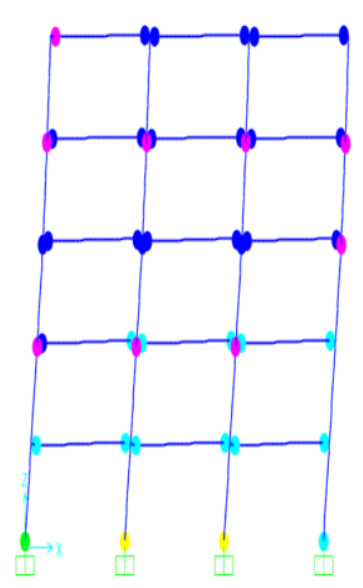

(e)

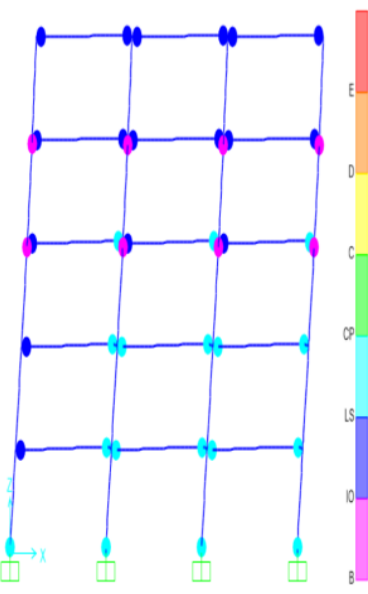

(f)
Figure: 4 Hinge patterns

In figure 4(b) shows the distribution of hinge formations in model-2, frame is considered in XZ plane @ $\mathrm{Y}=0$ hinges are formed in all stories of building in the range of B-CP, Frame model shows that first yield occurred at a displacement of 0 . $042 \mathrm{~m}$ with base shear of $2611.77 \mathrm{kN}$ and ultimate base shear was $6060.09 \mathrm{kN}$ with a displacement of $0.2448 \mathrm{~m}$ and formation of hinges are reduced compare to model-1.

In figure 4(c) shows the distribution of hinge formations in model-3, frame is considered in XZ plane @ Y=0 hinges are formed in all stories of building in the range of B-D. Frame model shows that first yield occurred at a displacement of $0.0417 \mathrm{~m}$ with base shear of $3158.36 \mathrm{kN}$ and ultimate base shear was $9203.33 \mathrm{kN}$ with a displacement of $0.3945 \mathrm{~m}$, and formation of hinges are reduced compare to model-2.

In figure 4(d) shows the hinge formations in model-4, frame is considered in XZ plane @ $\mathrm{Y}=0$ hinges are formed in all stories of building in the range of B-D, Frame model shows that first yield occurred at a displacement of $0.0430 \mathrm{~m}$ with base shear of $3919.36 \mathrm{kN}$ and ultimate base shear was $12650.07 \mathrm{kN}$ with a displacement of $0.4669 \mathrm{~m}$, and formation of hinges are reduced compare to model-3.

In figure 4(e) shows the hinge formations in model-5, frame is considered in XZ plane @ $\mathrm{Y}=0$ hinges are formed in all stories of building in the range of B-D, Frame model shows that first yield occurred at a displacement of $0.0428 \mathrm{~m}$ with base shear of $4741.95 \mathrm{kN}$ and ultimate base shear was $15220.67 \mathrm{kN}$ with a displacement of $0.5075 \mathrm{~m}$, and formation of hinges are reduced compare to model-4 and formation of column hinges are changed to beam hinges.

In figure 4(f) shows the hinge formations in model-6, frame is considered in XZ plane @ $\mathrm{Y}=0$ hinges are formed in all stories of building in the range of B-D, Frame model shows that first yield occurred at a displacement of $0.0415 \mathrm{~m}$ with base shear of $5669.50 \mathrm{kN}$ and ultimate base shear was $18850.0 \mathrm{kN}$ with a displacement of $0.5456 \mathrm{~m}$, and formation of hinges are reduced compare to model-5 and formation of column hinges are changed to beam hinges.

Finally, form the analysis of the RC frame building this can be achieved by formation of plastic hinges at the end regions of all the beams in all stories of building but columns are remaining elastic in all stories while the except of the base of the bottom story. 


\section{Non-Linear Performance of Strong Column Weak Beam RC Frame Building}

This will provide a strong column weak beam structure by eliminating the possibility of column sway mechanism of building and avoiding shear failure in columns and beams. It has been observed that in case of normal building the first story columns have been collapse and by increase column sizes it increases the capacity of structure. From this it has been understood that the building with area of cross section of column is more shows the better performance compare to the actual building.

\section{STORY DISPLACEMENT}

It is displacement caused by lateral forces on each story level of structure. Lateral displacement will be more on top story after analysis the building. In this study the effect of story displacement with respect to story number pushover analysis has been done for five story building with increasing the column sizes. The comparison of story displacement with respect to story number of models is shown in figure 5 .

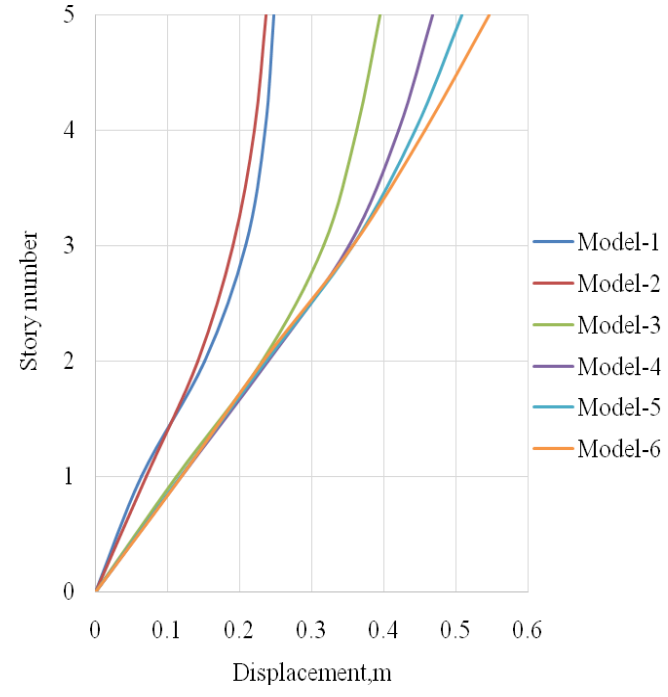

Figure.5 Story displacement vs. story number

Form the analysis of the building a comparative study has been done for the six-models it was observed.

Table: V Percentage of increasing the column sizes and displacement

\begin{tabular}{|l|l|l|}
\hline Building model & $\begin{array}{l}\text { Percentage of } \\
\text { size increasing } \\
\text { the column } \\
\text { section }\end{array}$ & $\begin{array}{l}\text { Percentage } \\
\text { displacement } \\
\text { increasing } \\
\text { / decreasing }\end{array}$ \\
\hline Model-1 & $\begin{array}{l}\text { Actual size of } \\
\text { column section }\end{array}$ & - \\
\hline Model-2 & $20 \%$ increasing & $4.05 \%$ decreasing \\
\hline Model-3 & $40 \%$ increasing & $60.04 \%$ increasing \\
\hline Model-4 & $60 \%$ increasing & $89.41 \%$ increasing \\
\hline Model-5 & $80 \%$ increasing & $105.88 \%$ increasing \\
\hline Model-6 & $100 \%$ increasing & $121.33 \%$ increasing \\
\hline
\end{tabular}

\section{CONCLUSIONS}

For the analysis of building without increasing the column sizes the flexural moments of column are less compare to the flexural moments of beam, when increasing the column sizes $20 \%, 40 \%, 60 \%$, $80 \%$ and $100 \%$ columns moments are increased.

1. When increasing the percentage of column sizes base shear also increasing. Base shear is increased by 266.64percentage when column size is increased by 100percentage.

2. Comparing all the model results displacement is less in model-2. But for other models' displacement is increased with increasing the percentage of column sizes. Displacement increased by 121.33percentage when the column size is increased by 100percentage.

3. By increasing the column sizes formation of plastic hinges in columns changed to beam hinges. Comparing to all models no collapse hinges are formed in model-2 and less collapse hinges are formed in model-6. Comparing model-2 and model-6 more base shear in model-6.

4. By comparison of all models, model-2 shows the best result. It has been concluded that increasing the 20percentage of column size shows less displacement and more base shear.

\section{REFERENCES}

1. Mitesh Surana · Yogendra Singh • Dominik H. Lang Effect of strong-column weak-beam design provision on the seismic fragility of RC frame buildings.International Journal of Advanced Structural Engineering (2018) 10:131-141.

2. Vaibhav Doshi. Influence of Strong Column Weak Beam Design as Per Draft Code IS:13920IJSTE - International Journal of Science Technology \& Engineering | Volume 2 | Issue 11 | May 2016.

3. Han-SeonLeel. Revised rule for concept of strong column weak girder design, journal of structural engineering / April 1996/359.

4. I Ketut Sudarsana, Ida Ayu Made Budiwati, Putu Wiyta Aditya, Effect of Column to Beam Strength Ratio on Performance of Reinforced Concrete Frames. DOI: 10.13140/RG.2.1.2161.9369

5. Hande GÖKDEMIR, Ayten GÜNAYDIN, Investigation of Strong Column- Weak Beam Ratio in Multi -Storey Structures, Gökdemir and Günaydın / Anadolu Univ. J. of Sci. and Technology A - Appl. Sci. And Eng. XX (X) - 201X

6. Rita BENTO And Mário LOPES, Evaluation of the need for strong column weak beam design in dual frame wall structures,Civil Engineering and Architecture Department - Instituto Superior Técnico 1049-001 Lisbon

7. B Shivakumara Swamy, S K Prasad, Sunil,Influence of strong column and weak beam concept, soil type and seismic zone performance of RC frames from pushover analysis International Journal of Research in Engineering and Technology, Volume: 04 Special Issue: 04 | ASHCE-2015 | May-2015.

8. Mr. Vikas Kadukar, Prof. R. B. Kulkarni, Prof. R. D. Deshpande Study on Literature Review of Strong Column Weak Beam Behavior of Frames International Journal for Research in Applied Science \& Engineering Technology Volume 6 Issue V, May 2018Indian Standard Code of Practice for Plain and Reinforced Concrete, IS 456-2000. Bureau of Indian Standards, New Delhi.

9. Nattapat Wongpakdee and Sutat Leelataviwat,InfluenceofColumnStrengthandStiffnessontheInelastic Behaviour of Strong-Column-Weak-Beam Frames. J. Struct. Eng., 2017, 143(9): 04017124.

10. Ririt Aprilin Sumarsono, Muhammad Aji Fajari,Improving seismic behaviour of irregular building through double column and console beam application,M ATEC Web of Conferences,258,05022 (2019). 


\section{AUTHORS PROFILE}

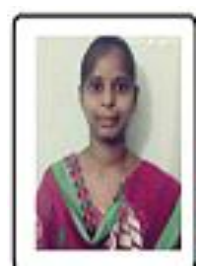

Jakkula Sony, M.Tech (Structural engineering),

Department of civil engineering, Anurag Group of Institutions, Hyderabad.

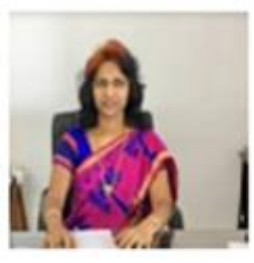

Dr. A. Vimala, ME Ph D. IIIT Hyderabad HOD Department of civil engineering, Anurag Group of Institutions, Hyderabad. 